\title{
Nitrogen Fertilization. A Review of the Risks Associated with the Inefficiency of Its Use and Policy Responses
}

\author{
Javier Martínez-Dalmau ${ }^{1, *(1)}$, Julio Berbel ${ }^{2, *}$ and Rafaela Ordóñez-Fernández ${ }^{3(1)}$ \\ 1 Departamento de Economía Agraria, Universidad de Córdoba, 14014 Córdoba, Spain \\ 2 Water, Environmental and Agricultural Resources Economics (WEARE) Research Group, \\ Universidad de Córdoba, 14014 Córdoba, Spain \\ 3 Area of Ecological Production and Natural Resources, IFAPA Centro Alameda del Obispo, \\ 14004 Córdoba, Spain; rafaelam.ordonez@juntadeandalucia.es \\ * Correspondence: javier.martinez@uco.es (J.M.-D.); berbel@uco.es (J.B.)
}

Citation: Martínez-Dalmau, J.;

Berbel, J.; Ordóñez-Fernández, R.

Nitrogen Fertilization. A Review of the Risks Associated with the Inefficiency of Its Use and Policy Responses. Sustainability 2021, 13, 5625. https://doi.org/10.3390/ su13105625

Academic Editor: Emanuele Radicett

Received: 9 March 2021

Accepted: 12 May 2021

Published: 18 May 2021

Publisher's Note: MDPI stays neutral with regard to jurisdictional claims in published maps and institutional affiliations.

Copyright: (c) 2021 by the authors. Licensee MDPI, Basel, Switzerland. This article is an open access article distributed under the terms and conditions of the Creative Commons Attribution (CC BY) license (https:// creativecommons.org/licenses/by/ $4.0 /)$.

\begin{abstract}
Nitrogen $(\mathrm{N})$ is a key input to food production. Nearly half of $\mathrm{N}$ fertilizer input is not used by crops and is lost into the environment via emission of gases or by polluting water bodies. It is essential to achieve production levels, which enable global food security, without compromising environmental security. The N pollution level expected by 2050 is projected to be $150 \%$ higher than in 2010 , with the agricultural sector accounting for $60 \%$ of this increase. In this paper, we review the status of the pollution from $\mathrm{N}$ fertilizers worldwide and make recommendations to address the situation. The analysis reviews the relationship between $\mathrm{N}$ fertilizer use, $\mathrm{N}$ use efficiency, nopoint pollution, the role of farmer management practices, and policy approaches to address diffuse pollution caused by $\mathrm{N}$ fertilization. Several studies show a lack of information as one of the main hurdles to achieve changes in habits. The objective of this study is to highlight the gravity of the current global non-point pollution as well as the need for a communication effort to make farmers aware of the relationship between their activity and $\mathrm{N}$ pollution and, therefore, the importance of their fertilizer management practices.
\end{abstract}

Keywords: review; nitrogen pollution; nitrogen-use efficiency; eutrophication; lixiviation; volatilization

\section{Introduction}

Nitrogen (N), carbon, hydrogen, oxygen, and phosphorus are the elements on which life is based [1]. Among them, $\mathrm{N}$ is the fundamental element in the formation of amino acids, which, in turn, are the basic components of proteins. This element makes up 78\% of the air in the atmosphere where it is practically inert and largely unreactive, existing mostly in molecular form $\left(\mathrm{N}_{2}\right)$. Nitrogen gas in the atmosphere is unsuitable for uptake by living matter. Human protein intake depends on the capacity of plants to take $\mathrm{N}$ into the food chain, and it requires certain transformations to be used by plants and later by animals for this to happen. Robertson and Groffman [2] defined the N cycle and its different forms. Atmospheric dinitrogen gas is turned into ammonia $\left(\mathrm{NH}_{3}\right)$ and fixed in the soil through the fixation process.

The $\mathrm{N}$ fixation relies on a series of microbial processes that transforms $\mathrm{N}_{2}$ into organic forms which then remain in the soil $[3,4]$. Biological fixation depends on a small range in water stress and aeration levels of the environment [5], so under natural conditions, the amounts of $\mathrm{N}$ fixed in soil is small [6,7]. Through the process of mineralization and nitrification, heterotrophic microorganisms transform this organic $\mathrm{N}$ from the soil into inorganic structures $\left(\mathrm{NH}_{4}{ }^{+}\right.$and $\left.\mathrm{NO}_{3}{ }^{-}\right)$that can readily be assimilated by plants [8]. These ions are the reactive forms of $\mathrm{N}$ available for biosynthesis, thus initiating the process of amino acid and protein formation. Due to the low rates of natural $\mathrm{N}$ cycle fixation, mineralization, and nitrification, $\mathrm{N}$ is the most limiting element in terrestrial ecosystems of all the soil nutrients needed for plant growth [9]. The emergence of synthetic $\mathrm{N}$ fertilizers 
from 1913 onwards triggered the development of the Green Revolution which, in turn, helped exponentially increase the world's population over the past century [10].

Nitrogen fertilizers used in agriculture increased from $10 \mathrm{Tg} \mathrm{N} \mathrm{ha}{ }^{-1}$ (1961) to $77 \mathrm{Tg} \mathrm{N} \mathrm{ha}{ }^{-1}$ (2016) [11,12]. Nearly half of the $\mathrm{N}$ fertilizer supplied is not used by crops and is lost to the ecosystem through volatilization, run-off, or leaching [13]. These losses lead to environmental problems, such as the release of greenhouse gases, pollution of water bodies, soil acidification, or biodiversity reduction. The atmospheric level of $\mathrm{N}$ pollution is expected by, 2050, to be in the range 102-156\% higher than in 2010 with the agricultural sector accounting for $60 \%$ of this increase $[12,14]$.

The concept of $\mathrm{N}$ use efficiency (NUE), as the biological capacity of the plant to assimilate $\mathrm{N}$, has been the subject of numerous previous reviews [15-19]. In this paper, we focus on reviewing the NUE as an anthropomorphic activity, and the negative consequences of $\mathrm{N}$ over-application in agriculture. The aim of this is to enhance the dissemination of good agricultural management practices.

This paper presents a systematic review of knowledge related to diffuse $\mathrm{N}$ pollution, best management practices, and improved farmer behavior. Current policies for managing diffuse pollution were initiated in the 1980s. We started our search in 1980, looking at the available academic and grey literature researching the factors which affect farmers management practices in relation to their capacity to improve diffuse pollution caused by their agricultural activity.

\section{Impact of Excess $\mathbf{N}$ in Agriculture}

Farmers in the developing world tend to over-fertilize $[20,21]$ because of the uncertain of variables such as weather and soil conditions. Management practices, based on the "fertilize for good years" rule, are consistent with maximizing expected returns under yield uncertainty, as the cost of over-application is less than the opportunity cost of underapplication [22]. The response of crops to fertilizer addition has often been modeled as a linear and plateau response (LRP) function that increases linearly until maximum yield is achieved, where the increase stops. This is assumed to be the standard agronomic model for response to water [23] and fertilizer, especially for N, where Liebig's law of minimum performs very well $[24,25]$. Due to the low NUE of the crops and the extreme mobility of the reactive forms of $\mathrm{N}$ in either the gas or the soluble phase, this excess $\mathrm{N}$ applied has a high risk to be lost to the environment [2,26-31]. The main characteristic of pollution of agricultural origin is its diffuse nature since its source cannot be easily traced [32]. The high volatility of ammonia and $\mathrm{N}$ oxides allows them to be transported through the atmosphere, and the high solubility of nitrate means that it is easily leached from the soil profile into aquatic ecosystems [13].

\subsection{Atmosphere Pollution}

Air pollution has direct consequences on human health. In 2017 five million people died from diseases related to air pollution, and the USA and China are among the 10 countries with the highest mortality rate [33]. Agricultural activities around the world are responsible for almost 15 percent of annual greenhouse gas emissions [34,35] and for $60-80 \%$ of global $\mathrm{N}_{2} \mathrm{O}$ emissions from human activity [36,37]. The increasing use of $\mathrm{N}$ fertilizers in food production worldwide has resulted in the raising of $\mathrm{N}_{2} \mathrm{O}$ concentrations in the atmosphere, where it remains as a greenhouse gas 298 times more potent than carbon dioxide [38]. Current $\mathrm{N}_{2} \mathrm{O}$ concentrations are starting to exceed the levels projected in most emission scenarios by the International Panel on Climate Change (IPCC) $[39,40]$ and are not compatible with the climate objectives of the Paris Agreement. Tian et al. [41] have conducted the first global assessment of nitrous oxide as one of the main greenhouse gases responsible for global warming, by comprehensively quantifying its global sources and sinks. According to their study, nitrous oxide is the third most important greenhouse gas after carbon dioxide and methane. Agricultural activity is the main cause of $\mathrm{N}_{2} \mathrm{O}$ pollution as it accounts for $70 \%$ of $\mathrm{N}_{2} \mathrm{O}$ emissions in the period between 2007 and 2016. Numerous stud- 
ies establish linear correlations between $\mathrm{N}$ fertilizer use in agriculture (including organic amendments) and $\mathrm{N}_{2} \mathrm{O}$ emissions worldwide [42-44]. However, several recent studies in corn cropping systems have reported an exponential relationship between them [45,46]. The current global mean value of $\mathrm{N}_{2} \mathrm{O}$, emitted by $\mathrm{N}$ fertilizers, is close to $0.9 \%$ of the $\mathrm{N}$ applied in cropland according to IPCC estimates [47]. This means that every $100 \mathrm{~kg}$ of $\mathrm{N}$ fertilizer used in agriculture emits $1.0 \mathrm{~kg}$ of $\mathrm{N}$ in $\mathrm{N}_{2} \mathrm{O}$ form into the atmosphere [45]. In 2018, $\mathrm{N}_{2} \mathrm{O}$ emissions from agriculture to the atmosphere were $7.718 \mathrm{Gg}$ [12].

\subsection{Aquatic Ecosystems Pollution}

Nitrate concentration is a critical indicator for measuring the level of pollution in aquatic ecosystems, as it is the most stable form of $\mathrm{N}$, and its high presence disrupts the vital balance of aquatic ecosystems [48,49]. The analysis of water pollution received an important boost from the studies by Kohl et al. [50], which in 1973 used N isotopes ( $815 \mathrm{~N}$ ) to analyze the influence of chemical fertilizers on the pollution of water bodies. Because of its effectiveness, this technique has been widely used to detect sources of nitrates in this environment [51,52].

Agriculture has been recognized as a major source of nitrate leaching pollution [53-56]. Nitrogen leaching is not only related to the amount of fertilizer applied, but also to other variables such as the timing and place of fertilizer applied in relation to the crop's growing cycle, irrigation regimes, type of fertilizer, agronomic practices, crop rotation, soil characteristics, type of soil cover, climate, etc. [57-63]. A sustainable population growth is not compatible with the degradation of groundwater reservoirs. Groundwater is increasingly being used as a source to meet growing water needs. Currently, groundwater accounts for $43 \%$ of irrigation water and more than $50 \%$ of domestic consumption worldwide [64]. Therefore, contamination of this resource seriously threatens the health of people who depend on its supply. Numerous studies show that continuous consumption of water with nitrate levels above $50 \mathrm{mg} / \mathrm{L}$ increases the likelihood of developing certain types of cancer [65-67].

Freshwater eutrophication can result from discharge of the nutrient-overloaded aquifer to a surface body. Eutrophication occurs when high concentrations of dissolved nutrients (especially $\mathrm{N}$ and phosphorus) meet stagnant aquatic ecosystems with restricted water input. Most eutrophication processes are caused by anthropogenic activities (agricultural fertilization, urban effluents, timber industry, recreational use of water resources, etc.). Currently, the main non-point source of high nutrient concentrations in freshwater is agricultural fertilization [68,69]. Grizzetti et al. [70] estimate the source of nitrogen at water bodies at European scale, finding a high variability, ranging from $90 \%$ to $10 \%$, as a function of the location and the level of urban wastewater treatment. The excess of inorganic compounds alters the ecosystem balance, reducing its biodiversity and giving to the cyanobacteria an opportunity to grow in a disorderly manner and end up collapsing the habitat [71,72]. The first studies of the toxins produced by cyanobacterial populations in contaminated aquatic environments began in the 1990s [73,74]. Cyanobacteria settle in the surface area of the water body, where the incidence of solar radiation is greatest, turning the water green and preventing light from reaching deeper areas [75]. Vegetation and many floating algae die when they fall below the new threshold of photosynthesis, due to the decrease in nutrients, where they are decomposed by bacteria that, in their activity, consume oxygen and produce toxins. Native aquatic species disappear, due to lack of oxygen, and are replaced by other species more adapted to anaerobic environments. At deeper levels, the low temperatures and the absence of oxygen and light constitute an unviable environment for life of the vernacular living beings [76].

Cyanobacteria produce toxins that are poisonous to certain living organisms, initiating the poisoning of the various links in the food chain until they reach human consumption [77]. Some of the adverse health effects are damage to the liver, intestines, and cardiovascular and central nervous systems [78-82]. In addition, cyanobacteria release various odorous substances that transform natural ecosystems into foul smelling areas $[79,83,84]$. 
The most common toxin-producing species in cyanobacteria include Anabaena circinalis, Aphanizomenon flos-aquae, Microcystis aeruginosa, and Cylindrospermopsis raciborskii [85,86]. Microcystins have been internationally assessed by the World Health Organization as cyanobacterial toxins for their health risk, which can cause acute liver injury and constitute active tumor promoters [67]. Europa, Oceania, and certain South American countries have integrated, into their national legislation, a threshold of microcystin-LR concentration in drinking water of $1 \mu \mathrm{g} / \mathrm{L}$ [87]. Many inland and coastal waters bodies worldwide are polluted by eutrophication [88] and life in certain seas is compromised. Since 1950, dead zones have been reported from more than 500 systems in coastal and inland water, affecting a total area of more than 300,000 square kilometers [89-91] Carpenter and Bennett [29] mention that wetland, lakes, and freshwater maximum tolerable limit of inputs nutrient receiving has already been crossed.

\section{Current Status of the Impacts of Excessive N Fertilization}

The analysis of historical trends in $\mathrm{N}$ fertilization seems to follow the environmental Kuznets curve (EKC) with a phase where $\mathrm{N}$ pollution increases and, later, decreases as economic development grows [92]. The EKC curve (bell-shaped) explains why developing countries remain in the phase of increasing pollution (e.g., India), certain countries are in the transition phase (e.g., China), while others are in a phase of reducing pollution (e.g., The USA and the EU).

\subsection{Developed Economies}

According Zhang et al. [92], the EU appears to have reached its turning point in the late 1980s, due to changes in the EU Common Agricultural Policy (reduced crop subsidies, and EU Nitrates Directive). On the other hand, the USA supports volunteer approaches and improvement has been modest since the 1990s, based on increased productivity (maintaining fertilizer use, increasing yields) and public and private efforts to improve NUE voluntarily. In 2017, the USA emitted to the atmosphere about $8 \%$ of the $\mathrm{N}_{2} \mathrm{O}$ emitted from $\mathrm{N}$ fertilization worldwide [12].

The EU approach is focused on best practices and nutrient balance and promotes the adoption of nutrient management planning (NMP); however, the rate of adoption of NMP by farmers remains slow compared with other word regions such as the USA or some South American countries [93]. Overall, the $\mathrm{N}$ loss from farmland to the environment is expressed in terms of $\mathrm{N}$ balance, which decreased from 2000 to 2015 and has been stable since 2015 [94]; however, $40 \%$ of surface waterbodies, and more than $50 \%$ of groundwater, in the EU were affected in 2015 by nutrient pollution, largely due to $\mathrm{N}$ fertilization and manure mismanagement. The nitrogen fertilization balance is checked by EU Member States but good practices and NMP are mainly verified through document examination without any soil analysis [95]. Several socio-economic variables (farm size, farmer age, etc.) have been suggested to explain the low adoption of NMP. Daxini et al. [96] analyze the factors behind the low adoption rate and conclude that farmer psychology needs to be better understood, in relation to the use of management practices, to provide both environmental and financial benefits.

\subsection{Transition Economies}

Developing countries, where $76 \%$ of the world population lives, use more $\mathrm{N}$ than developed countries. Asia is the greatest consumer of $\mathrm{N}$ fertilizer and energy in the world and is consequently responsible for a considerable proportion of the global creation of $\mathrm{N}_{2} \mathrm{O}$. Approximately $58 \%$ of $\mathrm{N}$ is currently emitted into the environment as a pollutant [12].

China is the second-largest country in the world with a cultivated area of 164 million ha, of which 63 million ha are irrigated land. Boosted by the policy goal of achieving a 95\% self-sufficiency rate, the Chinese government provides large amounts of subsidies for agricultural activity, including fertilization. Consequently, China is the world's largest fertilizer consumer with an average annual growth of $5.2 \%$ over the last three decades (2.5 times 
the EU growth rate) and accounts for more than one third of the chemical fertilizers consumption worldwide (equivalent to the USA and India consumption combined). [97]. The fertilizer used rate $(\mathrm{kg} / \mathrm{ha})$ in China is 2.8 times as that of the USA and 3.0 times as that of the world average [98]. In 2017, China used 29.55 million tons of $\mathrm{N}$ fertilizers, and emitted a total of 1275 gigagrams of $\mathrm{N}_{2} \mathrm{O}$ into the atmosphere [12]. Therefore, China urgently needs to formulate and implement effective measures to reduce greenhouse gas emissions from the agricultural sector [99].

Regarding eutrophication caused by leaching, there are multiple observations of high concentrations of cyanobacterial blooms in the Chinese river network (e.g., Xiang et al. [100]; Feng et al. [101]; 60\% of China's underground water is unfit for human consumption [102]. India, with 26.9 million tons of $\mathrm{N}$ fertilizer used in 2017, emitted 722.76 gigagrams of $\mathrm{N}_{2} \mathrm{O}$ into the atmosphere, and is the second-largest $\mathrm{N}_{2} \mathrm{O}$ emitter in the word after China [12]. Recently, evidence of high anthropogenic-induced $\mathrm{N}$ and phosphorus concentrations has been found in the Ganges basin, especially from Ramganga and Kali rivers. [103].

Despite the concerning situation in China and India, there are promising initiatives to reduce pollution from agricultural fertilizers. The Chinese government's 2015 action plan to avoid fertilizer use or the Indian government's support for the "Zero Budget Natural Agriculture" project to provide financial assistance to farmers, could prove to be good examples [104].

South and Central America recorded the largest increase in $\mathrm{N}$ use in agriculture over the last 10 years [12]. This is largely due to the deforestation that is taking place in the Brazilian Amazon to increase the agricultural land, which currently accounts for $28.8 \%$ of Brazil's surface area [105]. Brazil is the country with the largest volume of freshwater reserves in the world. However, the high level of water pollution in Brazil means that many parts of the country lack the drinking water necessary to meet basic needs [106-108], and agricultural water runoff with high concentration of nutrients and toxic elements is the cause of this level of pollution [109-111]. Toxic cyanobacterial blooms have been observed in certain lagoons on the coast of Brazil [85,86,112,113], in the mouth of its rivers [114], in its reservoirs [115,116], and in other waterbodies [117]. On the other hand, the $\mathrm{N}$ used by agriculture in Brazil during 2017 was the cause of the emission of 574.86 gigagrams of $\mathrm{N}_{2} \mathrm{O}$ into the atmosphere $\left(7.41 \%\right.$ of the $\mathrm{N}_{2} \mathrm{O}$ emitted worldwide). The rate of $\mathrm{NH}_{3}$ volatilization increases due to the fast hydrolysis of urea caused by high levels of tropical soil moisture and temperature [118]. This makes Brazil the fourth-largest emitter in the world of this harmful greenhouse gas, which is seriously affecting climate change, only behind China, India, and the USA [12]. Argentina is the second country in South America in terms of $\mathrm{N}_{2} \mathrm{O}$ emissions into the atmosphere with 152. $93 \mathrm{~g}$ in 2017 (almost $2 \%$ of the $\mathrm{N}_{2} \mathrm{O}$ emitted worldwide) [12,119]. Abril et al. [120] detected excessive doses of $\mathrm{N}$ fertilizers applied to wheat crops in the wet pampas that caused the leaching contamination of groundwater. The association between high groundwater levels and intense fertigation activity in agriculture has been verified in southeast Buenos Aires [121]. In the undulating Pampas, $40 \%$ of the assessed wells with access to the Pampean aquifer contained nitrate concentrations above the maximum recommended threshold for human consumption (45 ppm) [122].

\subsection{Developing Economies}

In Africa, due to the scarcity of surface water, potential socio-economic development relies on groundwater. The two main dangers in the use of groundwater are overexploitation and pollution of available reserves [123]. According to Usher [124], groundwater degradation is the most serious water-resource problem in Africa, and nitrate pollution is considered the major groundwater pollution issue. Africa, as a whole, has seen an increase in $\mathrm{N}$ fertilizer use of around 46\% over the period 2007-2017 [12].

Egypt utilizes $30 \%$ of all the $\mathrm{N}$ used in Africa in fertilization. The bulk of Egyptian agriculture is based in the Nile Delta, which is one of the largest river deltas in the world. Recently, Hegazy et al. [125] have found a concentration of nitrates $\left(\mathrm{NO}_{3}{ }^{-}\right)$and ammonium $\left(\mathrm{NH}_{4}{ }^{+}\right)$in the Nile Delta, of $25 \mathrm{mg} / \mathrm{L}$ and $3 \mathrm{mg} / \mathrm{L}$, respectively. Nigeria, due to the 
continuous expansion of its arable land, is the third-largest consumer of $\mathrm{N}$ fertilizers in Africa, only behind of Egypt and South Africa [12]. Nigeria has increased its arable land share of the country from $51.84 \%$ in 1981 to $77.36 \%$ in 2016 [98], and this has been accompanied by another increase in the use of fertilizers, which, in 2017, was 456 million tons with an estimated emission of $\mathrm{N}_{2} \mathrm{O}$ of 106.37 gigagrams [12].

\section{Nutrient Use Efficiency}

Nitrogen use efficiency is a term used generically in the agronomic literature. Nutrient use efficiency refers not only to the ability of crops to absorb nutrients, but also to their capacity to be used, and can therefore be defined in terms of production outputs relative to nutrient inputs or in terms of recovery of applied nutrients [126]. In this review, we find estimates made using agronomic, physiological, or economic criteria; calculations of $\mathrm{N}$ recovery based on measurements of grain quantity or grain plus biomass; data on $\mathrm{N}$ used to include $\mathrm{N}$ fixed in the soil from previous crops or not.

Partial Factor Productivity (PFP) analyzes the crop yield per unit of applied N. It is a useful indicator for farmers because of its easy calculation. However, for macro analysis it presents the difficulty that PFPs vary between crops, since each crop has different nutrient and water requirements. Fixen et al. [127] estimated a world average PFP of $44 \mathrm{~kg}$ of cereal per $\mathrm{kg}$ of N applied after analyzing the NUE of 25 consecutive years (1983-2007). Data for the period analyzed showed a slight increase in the NUE at the global level, driven by countries with developed economies, such as the USA, Germany, the United Kingdom, and Japan, with partial maximum factor productivity in Sub-Saharan Africa and minimum in East Asia. In general, the historical evolution shows an upward trend in the productivity of $\mathrm{N}$ used in Africa, the USA, and Europe, while in India, Latin America, and China it has been steadily decreasing.

Several studies show that the NUE is around 55\% worldwide. Ladha et al. [128] conducted an extensive analysis based on 93 studies obtaining a final result of $55 \%$ RE, which coincides with the estimate of $57 \%$ global NUE published by Sheldrick et al. [129] or with the official estimates from the USA of 56\% [130].

Recent studies estimate a global NUE of 43\% [131]. Zhang et al. [92] estimated that food security and environmental protection goals will not be achieved until the global average of the NUE increases from the current $\sim 0.4$ to $\sim 0.7$ (target 2050). The NUE obtained from research plots is often lower than that from farm fields [132]. Generally, the causes of low NUE are focused on technical aspects. However, a certain inefficiency may also be explained by socio-economic factors.

An increase in NUE rates implies a rational management of nutrients by the farmer in order to increase the efficiency of his resources, being more respectful with the environment while improving his economic profitability [133]. Many crop management practices can help reduce pollution from $\mathrm{N}$ fertilizers. The International Plant Nutrition Institute, the International Fertilizer Industry Association, the Fertilizer Institute, and the Canadian Fertilizer Institute have developed a framework for sustainable fertilizer management called "4R Nutrient Management". This framework is being implemented worldwide and synthesizes good practices in the field of fertilization in using the right nutrient source, applied at the right rate, at the right time, and in the right place, to achieve improved sustainability. These techniques are the basis of the Best Management Practice (BMP) that also include other practices aimed at reducing diffuse pollution such as buffer strips capable of retaining the $\mathrm{N}$ concentrations not absorbed by crops [134]; cover crops [135]; use of varieties that are genetically more efficient in the use of $\mathrm{N} \mathrm{[136];} \mathrm{increasing} \mathrm{in}$ appropriate crop rotations [137]; soil tillage systems [138]; fertilization strategies based on soil analysis [139]; methods based on $\mathrm{N}$ analysis in plant analysis [140] or dynamic computer simulation and decision support system [141]. 


\section{Policies for the Sustainable Management of N}

The efficiency of all these strategies and techniques has been widely proven to increase the NUE of crops and therefore, to reduce diffuse $\mathrm{N}$ pollution caused by the agricultural sector. However, these BMPs have not been widely accepted by farmers who encounter several barriers to changing their management practices [142,143]. The process of acceptance and implementation of BMPs by farmers is influenced by factors such as government policy, the psychological characteristics of the farmer, and the economic and agronomic characteristics of the farm $[144,145]$.

Understanding the decision-making process by farmers is fundamental to improving fertilizer management [131]. One of the psychological factors that represent a major obstacle to the adoption of these new practices is the widespread skepticism among farmers about climate change and the link between $\mathrm{N}$ fertilizers and climate change. An effort must be made to educate and publicize the risk of environmental pollution caused by $\mathrm{N}$ fertilization, the fatal consequences that we can already see today, and that have been analyzed above. Similarly, empowering farmers as a key element in the fight against climate change would minimize negative reactions [142]. Public policies aimed at reducing $\mathrm{N}$ pollution will not be fully successful until they are aligned with the mechanisms that motivate farmers to change their management practices. Emphasis should be placed on strengthening positive attitudes that highlight the benefits of adopting these BMPs [96].

\subsection{Policies}

Environmental policies in general aim to internalize, prevent, and correct the externalities of economic activities. Regarding $\mathrm{N}$ use as a fertilizer, the externalities are clearly stated in the previous sections and the policies are aimed at changing farmers' management practices. Each country has its own system of environmental regulation with different levels of requirements for farmers. Policies can be categorized broadly as: (a) mandatory measures, such as quotas, technical requirements, calendars, technologies; (b) voluntary and incentive-based measures, such as European CAP Eco schemes and cross compliance or EU Rural Development Funds; (c) awareness-raising and private initiatives.

Kanter et al. [131] propose the concept of a complete food chain NUE, as a new framework for analysing policies to reduce $\mathrm{N}$ pollution. In their study, they show that, given the close influence between all the actors in the food chain, $\mathrm{N}$ losses at farm level can be reduced by applying policies aimed at non-farmers.

The key policy instruments for diffuse $\mathrm{N}$ pollution in the EU are provided by the Nitrates Directive that was subsequently complemented by the Water Framework Directive [146]. Optimization of farmer management practices regarding fertilizer remains an objective of the CAP, which has included environmental sustainability since the reform in 2000 and defines monitoring as a central measure for Cross compliance under the PAC subsidies scheme. The result of monitoring shows that compliance with the Sludge Directive and the Habitat Directive was good but the N Directive was found to be deficient in various MS (EEA, 2020). In the USA, there are some fertilizer management regulations (manure and nutrient management planning or phosphorous index), but almost no federal standards related to agricultural fertilizer management are mandatory, the most of them are a system of voluntary programs. $\mathrm{NH}_{\mathrm{x}}$ emissions in the USA remain largely unregulated [147]. In China, the current regulation on $\mathrm{N}$ pollution is very weak. However, the high level of air and water pollution in many Chinese regions has forced the Chinese Ministry of Agriculture to initiate a reform of the subsidy system based on ecological principles [102].

\subsection{Social Intervention}

The main proposals for the reduction in excess nitrates involve a limitation of the total amount of $\mathrm{N}$ added per ha. World institutions such as OECD and EU endorse nutrient budgets as an environment indicator and promote the use of farm quotas. Farmers in the European Union are subject to the Nitrates Directive and the Emissions Ceiling 
Directive [131] although the review of current legislation in Europe by [148], finds that $\mathrm{N}$ budgets are obligatory only in Switzerland, Germany, and Romania.

The development of an inventory of existing and potential policies worldwide to improve agricultural $\mathrm{N}$ management would involve a vast task that exceeds the objective of this study, as each country has its own regulatory system with different levels of stringency. For example, in the USA, agricultural policy is based on voluntary programs such as the Environmental Quality Incentive Program. Regarding China, the most prolific user of $\mathrm{N}$ fertilizers worldwide, there is growing environmental awareness that demands improvement, and this is being matched by high-level policies, such as the renewed National Environmental Protection Law which establishes highly punitive sanctions for polluting companies that fail to comply with environmental regulations [149].

\subsection{Economic Instruments}

Regarding taxes, economists have argued that the price of fertilizer would have to be doubled in order to induce fertilizer savings [150], and the analysis of the EU experience with fertilizer taxation suggests that, overall, the effectiveness of pricing remains limited [151].

In terms of economic tools, the use of tradable nutrient-reduction permits has been suggested for the Baltic Sea Action Plan [152]. However, these policies are difficult to implement, and farmers are only one of several types of actors involved in the agrifood chain.

Alternative instruments for the improvement of EU N Directive pollution control have recently been analyzed by several authors, such as [153], who study alternatives for the reduction of nutrient surplus $(\mathrm{N})$ on dairy farms, and conclude that manure application standards would be more effective in limiting nutrient surplus to soils compared to the use of nutrient surplus tax.

\subsection{Technical Innovations}

The dominant approach towards improving NUE is technological and can be defined by the ' 4 Rs' label: applying the right supply, at the right rate, at the right time, in the right place. In addition to the $4 \mathrm{R}$ concept promoted in the USA, effective practices include adaptive management and on-farm research where farmers are organized locally to collect data on their fields and optimize their $\mathrm{N}$ fertilizer management. This strategic approach is complemented with research and innovation in the fields of plant breeding, irrigation, and agronomic practice. New technological developments are also needed, such as slow-release and controlled-release fertilizers, whose aim is to release $\mathrm{N}$ as the crop requires, thereby reducing the loss of applied N fertilizer and increasing the NUE. Additionally, certain authors promote the use of nitrification and urease inhibitors that are now widely applied in agriculture [154].

Precision irrigation and drip irrigation also constitute a growing trend promoted by many governments [155]. The implementation of water conservation technologies also facilitates the use of fertigation (the application of fertilizer via irrigation water).

Chen et al. [102] show that subsidizing innovation is a valid tool for reducing emissions from agriculture. While production subsidies are not environmentally friendly (e.g., China), innovation subsidies decrease the total emission of pollutants while helping to increase the farmer's margin.

\section{Conclusions}

Diffuse pollution, caused by $\mathrm{N}$ fertilization in agriculture, has become a global problem that is difficult to solve. Through a systematic review of published documents, we have analyzed the relationship between $\mathrm{N}$ fertilizer use, NUE, no-point pollution, policies, and farmer management practices. The results show that the trend in $\mathrm{N}$ fertilizer use worldwide continues increasing. Only the most economically developed countries (EU and the USA) are starting to moderate their growth rate of $\mathrm{N}$ use in agriculture in relation 
to their crop yields. In addition to this level of fertilization, studies show that we continue with a very low NUE (around 40\% worldwide), leaving around $60 \%$ of $\mathrm{N}$ used as a potential environmental pollutant. Numerous studies show the direct relationship between agricultural $\mathrm{N}$ fertilization and diffuse pollution through volatilization, leaching and runoff. The key to reduce this pollution is to increase the NUE. There is also a lot of literature focused on describing, developing, and demonstrating the effectiveness of techniques and procedures that help to improve NUE and reduce its negative effects both locally and globally. Some of these practices have been incorporated into the legislation of some countries (mainly in the European Union). However, these standards have not been generally accepted by farmers, who are reluctant to put them into practice. Existing studies in this area link awareness, willingness, and management change. Some studies report on the defensive attitude of farmers promoted by the lack of information on the reality and magnitude of the problem caused by $\mathrm{N}$ fertilization.

The complexity, and current level, of diffuse pollution suggests a better understanding of the factors that influence the management practices of farmers. This will lead to more effective policies that can be designed and applied to implement BMPs in a generalized way and, ultimately, reduce diffuse N pollution through the improvement of the NUE.

Author Contributions: The authors contributed equally to this work. All authors have read and agreed to the published version of the manuscript.

Funding: Project PID2019-107127RB-I00 (Agencia Estatal de Investigación, Spain) and research Group SEJ-592 (Junta de Andalucía, Spain).

Conflicts of Interest: The authors declare no conflict of interest.

\section{References}

1. Fowler, D.; Coyle, M.; Skiba, U.; Sutton, M.A.; Cape, J.N.; Reis, S.; Sheppard, L.J.; Jenkins, A.; Grizzetti, B.; Galloway, J.N. The global nitrogen cycle in the twenty-first century. Philos. Trans. R. Soc. B Biol. Sci. 2013, 368, 20130164. [CrossRef] [PubMed]

2. Robertson, G.P.; Groffman, P.M. 13-NITROGEN TRANSFORMATIONS. In Soil Microbiology, Ecology and Biochemistry, 3rd ed.; Paul, E.A., Ed.; Academic Press: San Diego, CA, USA, 2007; pp. 341-364. [CrossRef]

3. Galloway, J.N.; Schlesinger, W.H.; Levy, H.; Michaels, A.; Schnoor, J.L. Nitrogen fixation: Anthropogenic enhancementenvironmental response. Glob. Biogeochem. Cycles 1995, 9, 235-252. [CrossRef]

4. Zahran, H.H. Rhizobium-legume symbiosis and nitrogen fixation under severe conditions and in an arid climate. Microbiol. Mol. Biol. Rev. 1999, 63, 968-989. [CrossRef] [PubMed]

5. Albrecht, S.L.; Bennett, J.M.; Boote, K.J. Relationship of nitrogenase activity to plant water stress in field-grown soybeans. Field Crop. Res. 1984, 8, 61-71. [CrossRef]

6. Veluci, R.M.; Neher, D.A.; Weicht, T.R. Nitrogen fixation and leaching of biological soil crust communities in mesic temperate soils. Microb. Ecol. 2006, 51, 189-196. [CrossRef]

7. Andreu Lahoz, J.; Betrán Aso, J.; Delgado Enguita, I.; Espada Carbó, J.L.; Gil Martínez, M.; Gutiérrez López, M.; Iguácel Soteras, F.; Isla Climente, R.; Muñoz Pérez, F.; Orús Pueyo, F. Fertilización Nitrogenada: Guía de Actualización; Gobierno de Aragón, Centro de Transferencia Agroalimentaria: Zaragoza, Spain, 2006.

8. Binkley, D.; Hart, S.C. The Components of Nitrogen Availability Assessments in Forest Soils. In Advances in Soil Science; Springer: New York, NY, USA, 1989; pp. 57-112. [CrossRef]

9. Vitousek, P.M.; Aber, J.D.; Howarth, R.W.; Likens, G.E.; Matson, P.A.; Schindler, D.W.; Schlesinger, W.H.; Tilman, D.G. Human alteration of the global nitrogen cycle: Sources and consequences. Ecol. Appl. 1997, 7, 737-750. [CrossRef]

10. Gruber, N.; Galloway, J.N. An Earth-system perspective of the global nitrogen cycle. Nature 2008, 451, 293-296. [CrossRef] [PubMed]

11. Elrys, A.S.; Metwally, M.S.; Raza, S.; Alnaimy, M.A.; Shaheen, S.M.; Chen, Z.; Zhou, J. How much nitrogen does Africa need to feed itself by 2050? J. Environ. Manag. 2020, 268, 110488. [CrossRef] [PubMed]

12. FAO. FAOStat Database Collections. Available online: http://www.fao.org/faostat/en/\#country (accessed on 5 November 2020).

13. Billen, G.; Garnier, J.; Lassaletta, L. The nitrogen cascade from agricultural soils to the sea: Modelling nitrogen transfers at regional watershed and global scales. Philos. Trans. R. Soc. B Biol. Sci. 2013, 368, 20130123. [CrossRef]

14. Bodirsky, B.L.; Popp, A.; Lotze-Campen, H.; Dietrich, J.P.; Rolinski, S.; Weindl, I.; Schmitz, C.; Müller, C.; Bonsch, M.; Humpenöder, F. Reactive nitrogen requirements to feed the world in 2050 and potential to mitigate nitrogen pollution. Nat. Commun. 2014, 5, 1-7. [CrossRef]

15. Good, A.G.; Shrawat, A.K.; Muench, D.G. Can less yield more? Is reducing nutrient input into the environment compatible with maintaining crop production? Trends Plant Sci. 2004, 9, 597-605. [CrossRef] [PubMed] 
16. Rathke, G.W.; Behrens, T.; Diepenbrock, W. Integrated nitrogen management strategies to improve seed yield, oil content and nitrogen efficiency of winter oilseed rape (Brassica napus L.): A review. Agric. Ecosyst. Environ. 2006, 117, 80-108. [CrossRef]

17. Han, M.; Okamoto, M.; Beatty, P.H.; Rothstein, S.J.; Good, A.G. The genetics of nitrogen use efficiency in crop plants. Annu. Rev. Genet 2015, 49, 269-289. [CrossRef]

18. Bouchet, A.-S.; Laperche, A.; Bissuel-Belaygue, C.; Snowdon, R.; Nesi, N.; Stahl, A. Nitrogen use efficiency in rapeseed. A review. Agron. Sustain. Dev. 2016, 36, 38. [CrossRef]

19. Salim, N.; Raza, A. Nutrient use efficiency (NUE) for sustainable wheat production: A review. J. Plant Nutr. 2020, 43, 297-315. [CrossRef]

20. Yang, L.; Deng, Y.; Wang, X.; Zhang, W.; Shi, X.; Chen, X.; Lakshmanan, P.; Zhang, F. Global direct nitrous oxide emissions from the bioenergy crop sugarcane (Saccharum spp. inter-specific hybrids). Sci. Total Environ. 2021, 752, 141795. [CrossRef] [PubMed]

21. Coskun, D.; Britto, D.T.; Shi, W.; Kronzucker, H.J. Nitrogen transformations in modern agriculture and the role of biological nitrification inhibition. Nat. Plants 2017, 3, 17074. [CrossRef] [PubMed]

22. Weersink, A.; Rajsic, P.; Gandorfer, M. Risk and Nitrogen Application Levels. Can. J. Agric. Econ. /Rev. Can. D'agroeconomie 2009, 57, 223-239. [CrossRef]

23. Steduto, P.; Hsiao, T.C.; Fereres, E.; Raes, D. Crop Yield Response to Water; Food and Agriculture Organization of the United Nations Rome: Rome, Italy, 2012; Volume 1028.

24. Cerrato, M.; Blackmer, A. Comparison of models for describing; corn yield response to nitrogen fertilizer. Agron. J. 1990, 82, 138-143. [CrossRef]

25. Grimm, S.S.; Paris, Q.; Williams, W.A. A von Liebig model for water and nitrogen crop response. West. J. Agric. Econ. 1987, 182-192.

26. Ferguson, S.J. Denitrification and its control. Antonie Van Leeuwenhoek 1994, 66, 89-110. [CrossRef]

27. Knowles, R. Denitrification. Microbiol. Rev. 1982, 46, 43. [CrossRef] [PubMed]

28. Arp, D.J.; Sayavedra-Soto, L.A.; Hommes, N.G. Molecular biology and biochemistry of ammonia oxidation by Nitrosomonas europaea. Arch. Microbiol. 2002, 178, 250-255. [CrossRef] [PubMed]

29. Carpenter, S.R.; Bennett, E.M. Reconsideration of the planetary boundary for phosphorus. Environ. Res. Lett. 2011, 6, 014009. [CrossRef]

30. Sahrawat, K.L. Nitrification in some tropical soils. Plant Soil 1982, 65, 281-286. [CrossRef]

31. Tubiello, F.N.; Salvatore, M.; Rossi, S.; Ferrara, A.; Fitton, N.; Smith, P. The FAOSTAT database of greenhouse gas emissions from agriculture. Environ. Res. Lett. 2013, 8, 015009. [CrossRef]

32. La Nauze, A.; Mezzetti, C. Dynamic incentive regulation of diffuse pollution. J. Environ. Econ. Manag. 2019, 93, 101-124. [CrossRef]

33. Shakoor, A.; Chen, X.; Farooq, T.H.; Shahzad, U.; Ashraf, F.; Rehman, A.; Sahar, N.E.; Yan, W. Fluctuations in environmental pollutants and air quality during the lockdown in the USA and China: Two sides of COVID-19 pandemic. Air Qual. Atmos. Health 2020, 13, 1335-1342. [CrossRef]

34. Nelson, G.C. Agriculture and Climate Change: An Agenda for Negotiation in Copenhagen; International Food Policy Research Institute (IFPRI): Washington, DC, USA, 2009.

35. Springmann, M.; Clark, M.; Mason-D'Croz, D.; Wiebe, K.; Bodirsky, B.L.; Lassaletta, L.; de Vries, W.; Vermeulen, S.J.; Herrero, M.; Carlson, K.M.; et al. Options for keeping the food system within environmental limits. Nature 2018, 562, 519-525. [CrossRef]

36. Yoom, S.; Song, B.; Phillips, R.L.; Chang, J.; Song, M.J. Ecological and physiological implications of nitrogen oxide reduction pathways on greenhouse gas emissions in agroecosystems. FEMS Microbiol. Ecol. 2019, 95, fiz066. [CrossRef]

37. Ravishankara, A.; Daniel, J.S.; Portmann, R.W. Nitrous oxide (N2O): The dominant ozone-depleting substance emitted in the 21st century. Science 2009, 326, 123-125. [CrossRef] [PubMed]

38. Aguilera, E.; Piñero, P.; Infante Amate, J.; González de Molina, M.; Lassaletta, L.; Sanz Cobeña, A. Emisiones de gases de efecto invernadero en el sistema agroalimentario y huella de carbono de la alimentación en España. Real Academia de Ingeniería. $2020,35$.

39. Pachauri, R.K.; Allen, M.R.; Barros, V.R.; Broome, J.; Cramer, W.; Christ, R.; Church, J.A.; Clarke, L.; Dahe, Q.; Dasgupta, P. Climate Change 2014: Synthesis Report. Contribution of Working Groups I, II and III to the Fifth Assessment Report of the Intergovernmental Panel on Climate Change; Pachauri, R.K., Meyer, L.A., Eds.; IPCC: Geneva, Switzerland, 2014; pp. 1-151.

40. Thompson, R.; Lassaletta, L.; Patra, P.; Wilson, C.; Wells, K.; Gressent, A.; Koffi, E.; Chipperfield, M.; Winiwarter, W.; Davidson, E. Acceleration of global N 2 O emissions seen from two decades of atmospheric inversion. Nat. Clim. Chang. 2019, 9, 993-998. [CrossRef]

41. Tian, H.; Xu, R.; Canadell, J.G.; Thompson, R.L.; Winiwarter, W.; Suntharalingam, P.; Davidson, E.A.; Ciais, P.; Jackson, R.B.; Janssens-Maenhout, G. A comprehensive quantification of global nitrous oxide sources and sinks. Nature 2020, 586, $248-256$. [CrossRef]

42. Bouwman, A.F. Direct emission of nitrous oxide from agricultural soils. Nutr. Cycl. Agroecosystems 1996, 46, 53-70. [CrossRef]

43. Dobbie, K.; McTaggart, I.P.; Smith, K. Nitrous oxide emissions from intensive agricultural systems: Variations between crops and seasons, key driving variables, and mean emission factors. J. Geophys. Res. Atmos. 1999, 104, 26891-26899. [CrossRef]

44. Kroeze, C.; Mosier, A.; Nevison, C.; Oenema, O.; Seitzinger, S.; van Cleemput, O.; Conrad, R.; Mitra, A.; HU N, S.R. Revised 1996 IPCC guidelines for national greenhouse gas inventories. Intergov. Panel Clim. Chang. 1997. 
45. Shcherbak, I.; Millar, N.; Robertson, G.P. Global metaanalysis of the nonlinear response of soil nitrous oxide (N2O) emissions to fertilizer nitrogen. Proc. Natl. Acad. Sci. USA 2014, 111, 9199-9204. [CrossRef] [PubMed]

46. Wang, X.; Zou, C.; Gao, X.; Guan, X.; Zhang, W.; Zhang, Y.; Shi, X.; Chen, X. Nitrous oxide emissions in Chinese vegetable systems: A meta-analysis. Environ. Pollut. 2018, 239, 375-383. [CrossRef]

47. Stehfest, E.; Bouwman, L. N $2 \mathrm{O}$ and NO emission from agricultural fields and soils under natural vegetation: Summarizing available measurement data and modeling of global annual emissions. Nutr. Cycl. Agroecosystems 2006, 74, 207-228. [CrossRef]

48. Keuskamp, J.A.; van Drecht, G.; Bouwman, A.F. European-scale modelling of groundwater denitrification and associated N2O production. Environ. Pollut. 2012, 165, 67-76. [CrossRef] [PubMed]

49. Nejatijahromi, Z.; Nassery, H.R.; Hosono, T.; Nakhaei, M.; Alijani, F.; Okumura, A. Groundwater nitrate contamination in an area using urban wastewaters for agricultural irrigation under arid climate condition, southeast of Tehran, Iran. Agric. Water Manag. 2019, 221, 397-414. [CrossRef]

50. Kohl, D.; Shearer, G.; Commoner, B. Variation of $15 \mathrm{~N}$ in corn and soil following application of fertilizer nitrogen. Soil Sci. Soc. Am. J. 1973, 37, 888-892. [CrossRef]

51. Kellman, L.M.; Hillaire-Marcel, C. Evaluation of nitrogen isotopes as indicators of nitrate contamination sources in an agricultural watershed. Agric. Ecosyst. Environ. 2003, 95, 87-102. [CrossRef]

52. Liu, X.-L.; Han, G.; Zeng, J.; Liu, M.; Li, X.-Q.; Boeckx, P. Identifying the sources of nitrate contamination using a combined dual isotope, chemical and Bayesian model approach in a tropical agricultural river: Case study in the Mun River, Thailand. Sci. Total Environ. 2020, 760, 143938. [CrossRef] [PubMed]

53. Liu, R.; Zhang, P.; Wang, X.; Chen, Y.; Shen, Z. Assessment of effects of best management practices on agricultural non-point source pollution in Xiangxi River watershed. Agric. Water Manag. 2013, 117, 9-18. [CrossRef]

54. Haas, M.B.; Guse, B.; Fohrer, N. Assessing the impacts of Best Management Practices on nitrate pollution in an agricultural dominated lowland catchment considering environmental protection versus economic development. J. Environ. Manag. 2017, 196, 347-364. [CrossRef]

55. Abrantes, N.; Pereira, R.; Gonçalves, F. First step for an ecological risk assessment to evaluate the impact of diffuse pollution in Lake Vela (Portugal). Environ. Monit. Assess. 2006, 117, 411-431. [CrossRef]

56. Ball, D.; MacDonald, A.; Lilly, A. Agriculture and diffuse pollution: Groundwater nitrate vulnerable zones in Scotland. Scott. J. Geol. 2005, 41, 61-68. [CrossRef]

57. Alva, A.; Paramasivam, S.; Fares, A.; Obreza, T.; Schumann, A. Nitrogen best management practice for citrus trees: II. Nitrogen fate, transport, and components of N budget. Sci. Hortic. 2006, 109, 223-233. [CrossRef]

58. Barton, L.; Colmer, T.D. Irrigation and fertiliser strategies for minimising nitrogen leaching from turfgrass. Agric. Water Manag. 2006, 80, 160-175. [CrossRef]

59. Karandish, F.; Šimůnek, J. Two-dimensional modeling of nitrogen and water dynamics for various N-managed water-saving irrigation strategies using HYDRUS. Agric. Water Manag. 2017, 193, 174-190. [CrossRef]

60. Jia, X.; Shao, L.; Liu, P.; Zhao, B.; Gu, L.; Dong, S.; Bing, S.H.; Zhang, J.; Zhao, B. Effect of different nitrogen and irrigation treatments on yield and nitrate leaching of summer maize (Zea mays L.) under lysimeter conditions. Agric. Water Manag. 2014, 137, 92-103. [CrossRef]

61. Jia, Y.; Hu, Z.; Ba, Y.; Qi, W. Application of biochar-coated urea controlled loss of fertilizer nitrogen and increased nitrogen use efficiency. Chem. Biol. Technol. Agric. 2021, 8, 1-11. [CrossRef]

62. De Notaris, C.; Mortensen, E.Ø.; Sørensen, P.; Olesen, J.E.; Rasmussen, J. Cover crop mixtures including legumes can self-regulate to optimize N2 fixation while reducing nitrate leaching. Agric. Ecosyst. Environ. 2021, 309, 107287. [CrossRef]

63. Dai, Z.; Hu, J.; Fan, J.; Fu, W.; Wang, H.; Hao, M. No-tillage with mulching improves maize yield in dryland farming through regulating soil temperature, water and nitrate-N. Agric. Ecosyst. Environ. 2021, 309, 107288. [CrossRef]

64. Carrard, N.; Foster, T.; Willetts, J. Groundwater as a source of drinking water in southeast Asia and the Pacific: A multi-country review of current reliance and resource concerns. Water 2019, 11, 1605. [CrossRef]

65. Fewtrell, L. Drinking-Water Nitrate, Methemoglobinemia, and Global Burden of Disease: A Discussion. Environ. Health Perspect. 2004, 112, 1371-1374. [CrossRef]

66. Nikolenko, O.; Jurado, A.; Borges, A.V.; Knöller, K.; Brouyère, S. Isotopic composition of nitrogen species in groundwater under agricultural areas: A review. Sci. Total Environ. 2018, 621, 1415-1432. [CrossRef]

67. World Health Organization. Guidelines for Drinking-Water Quality; World Health Organization: Geneva, Swizerland, 1993; ISBN 924154460.

68. Smith, V.H. Cultural eutrophication of inland, estuarine, and coastal waters. In Successes, Limitations, and Frontiers in Ecosystem Science; Springer: Berlin/Heidelberg, Germany, 1998; pp. 7-49.

69. Vollenweider, R.; Kerekes, J. Eutrophication of waters, Monitoring. Assess. Control. OecdParis 1982, 154.

70. Grizzetti, B.; Bouraoui, F.; De Marsily, G. Assessing nitrogen pressures on European surface water. Glob. Biogeochem. Cycles 2008, 22. [CrossRef]

71. Jeppesen, E.; Kristensen, P.; Jensen, J.P.; Søndergaard, M.; Mortensen, E.; Lauridsen, T. Recovery resilience following a reduction in external phosphorus loading of shallow, eutrophic Danish lakes: Duration, regulating factors and methods for overcoming resilience. Mem. Ist. Ital. Idrobiol. 1991, 48, 127-148. 
72. Seehausen, O.; Van Alphen, J.J.; Witte, F. Cichlid fish diversity threatened by eutrophication that curbs sexual selection. Science 1997, 277, 1808-1811. [CrossRef]

73. Chorus, I.; Bartram, J. Toxic Cyanobacteria in Water: A Guide to Their Public Health Consequences, Monitoring and Management; CRC Press: Boca Raton, FL, USA, 1999.

74. Jochimsen, E.M.; Carmichael, W.W.; An, J.; Cardo, D.M.; Cookson, S.T.; Holmes, C.E.; Antunes, M.B.; de Melo Filho, D.A.; Lyra, T.M.; Barreto, V.S.T. Liver failure and death after exposure to microcystins at a hemodialysis center in Brazil. N. Engl. J. Med. 1998, 338, 873-878. [CrossRef] [PubMed]

75. Baker, P.; Humpage, A. Toxicity associated with commonly occurring cyanobacteria in surface waters of the Murray-Darling Basin, Australia. Mar. Freshw. Res. 1994, 45, 773-786. [CrossRef]

76. Alexander, R.B.; Smith, R.A. Trends in the nutrient enrichment of US rivers during the late 20th century and their relation to changes in probable stream trophic conditions. Limnol. Oceanogr. 2006, 51, 639-654. [CrossRef]

77. Carmichael, W.W. Health Effects of Toxin-Producing Cyanobacteria: “The CyanoHABs". Hum. Ecol. Risk Assess. Int. J. 2001, 7, 1393-1407. [CrossRef]

78. Massey, I.Y.; Yang, F.; Ding, Z.; Yang, S.; Guo, J.; Al-Osman, M.; Kamegni, R.B.; Zeng, W. Exposure routes and health effects of microcystins on animals and humans: A mini-review. Toxicon 2018, 151, 156-162. [CrossRef]

79. Cao, L.; Huang, F.; Massey, I.Y.; Wen, C.; Zheng, S.; Xu, S.; Yang, F. Effects of microcystin-LR on the microstructure and inflammation-related factors of jejunum in mice. Toxins 2019, 11, 482. [CrossRef]

80. Huang, F.; Feng, H.; Li, X.; Yi, X.; Guo, J.; Clara, T.; Yang, F. Anaerobic degradation of microcystin-LR by an indigenous bacterial Enterobacter sp. YF3. J. Toxicol. Environ. HealthPart A 2019, 82, 1120-1128. [CrossRef] [PubMed]

81. Wen, C.; Zheng, S.; Yang, Y.; Li, X.; Chen, J.; Wang, X.; Feng, X.; Yang, F. Effects of microcystins-LR on genotoxic responses in human intestinal epithelial cells (NCM460). J. Toxicol. Environ. HealthPart A 2019, 82, 1113-1119. [CrossRef] [PubMed]

82. Yang, Y.; Wen, C.; Zheng, S.; Liu, W.; Chen, J.; Feng, X.; Wang, X.; Yang, F.; Ding, Z. Influence of microcystins-LR (MC-LR) on autophagy in human neuroblastoma SK-N-SH cells. J. Toxicol. Environ. HealthPart A 2019, 82, 1129-1136. [CrossRef]

83. Massey, I.Y.; Zhang, X.; Yang, F. Importance of bacterial biodegradation and detoxification processes of microcystins for environmental health. J. Toxicol. Environ. HealthPart B 2018, 21, 357-369. [CrossRef] [PubMed]

84. Zhang, C.; Massey, I.Y.; Liu, Y.; Huang, F.; Gao, R.; Ding, M.; Xiang, L.; He, C.; Wei, J.; Li, Y. Identification and characterization of a novel indigenous algicidal bacterium Chryseobacterium species against Microcystis aeruginosa. J. Toxicol. Environ. HealthPart A 2019, 82, 845-853. [CrossRef] [PubMed]

85. Azevedo, S.M.; Evans, W.R.; Carmichael, W.W.; Namikoshi, M. First report of microcystins from a Brazilian isolate of the cyanobacteriumMicrocystis aeruginosa. J. Appl. Phycol. 1994, 6, 261-265. [CrossRef]

86. Lagos, N.; Onodera, H.; Zagatto, P.A.; Andrinolo, D.o.; Azevedo, S.M.; Oshima, Y. The first evidence of paralytic shellfish toxins in the freshwater cyanobacterium Cylindrospermopsis raciborskii, isolated from Brazil. Toxicon 1999, 37, 1359-1373. [CrossRef]

87. Falconer, I.R.; Humpage, A.R. Health risk assessment of cyanobacterial (blue-green algal) toxins in drinking water. Int. J. Environ. Res. Public Health 2005, 2, 43-50. [CrossRef] [PubMed]

88. Mateo-Sagasta, J.; Burke, J. Agriculture and water quality interactions. In SOLAW Background Thematic Report TR08; FAO: Rome, Italy, 2010; Available online: http:/ / www.fao.org/nr/solaw/ (accessed on 11 December 2020).

89. Diaz, R.J.; Rosenberg, R. Spreading Dead Zones and Consequences for Marine Ecosystems. Science 2008, 321, 926-929. [CrossRef]

90. Goudie, A.S. Human Impact on the Natural Environment; John Wiley \& Sons: Hoboken, NJ, USA, 2018.

91. Breitburg, D.; Levin, L.A.; Oschlies, A.; Grégoire, M.; Chavez, F.P.; Conley, D.J.; Garçon, V.; Gilbert, D.; Gutiérrez, D.; Isensee, K. Declining oxygen in the global ocean and coastal waters. Science 2018, 359. [CrossRef]

92. Zhang, X.; Davidson, E.A.; Mauzerall, D.L.; Searchinger, T.D.; Dumas, P.; Shen, Y. Managing nitrogen for sustainable development. Nature 2015, 528, 51-59. [CrossRef] [PubMed]

93. Ulrich-Schad, J.D.; de Jalón, S.G.; Babin, N.; Pape, A.; Prokopy, L.S. Measuring and understanding agricultural producers' adoption of nutrient best management practices. J. Soil Water Conserv. 2017, 72, 506-518. [CrossRef]

94. Eurostat. Agri-Environmental Indicator-Gross Nitrogen Balance. Available online: https://ec.europa.eu/eurostat/statisticsexplained/index.php?title=Agri-environmental_indicator_-_gross_nitrogen_balance (accessed on 20 January 2021).

95. Commission, E. Evaluation of the Impact of the CAP on Water; European Commission: Luxembourg, 2020.

96. Daxini, A.; Ryan, M.; O'Donoghue, C.; Barnes, A.P. Understanding farmers' intentions to follow a nutrient management plan using the theory of planned behaviour. Land Use Policy 2019, 85, 428-437. [CrossRef]

97. Flores, I. Agroquímicos en China. In ICEX. Instituto de Comercio Exterior. Ministerio de Industria Cormercio y Turismo; Oficina Económica y Comercial de la Embajada de España en Shanghái: Shanghái, China, 2018.

98. WBOD. (World Bank Open Data). 2020. Available online: http:// data.worldbank.org/ (accessed on 15 December 2020).

99. Wang, Z.-B.; Chen, J.; Mao, S.-C.; Han, Y.-C.; Chen, F.; Zhang, L.-F.; Li, Y.-B.; Li, C.-D. Comparison of greenhouse gas emissions of chemical fertilizer types in China's crop production. J. Clean. Prod. 2017, 141, 1267-1274. [CrossRef]

100. Xiang, L.; Li, Y.-W.; Liu, B.-L.; Zhao, H.-M.; Li, H.; Cai, Q.-Y.; Mo, C.-H.; Wong, M.-H.; Li, Q.X. High ecological and human health risks from microcystins in vegetable fields in southern China. Environ. Int. 2019, 133, 105142. [CrossRef] [PubMed]

101. Feng, H.; Clara, T.; Huang, F.; Wei, J.; Yang, F. Identification and characterization of the dominant Microcystis sp. cyanobacteria detected in Lake Dong Ting, China. J. Toxicol. Environ. HealthPart A 2019, 82, 1143-1150. [CrossRef] 
102. Chen, Y.-H.; Wen, X.-W.; Wang, B.; Nie, P.-Y. Agricultural pollution and regulation: How to subsidize agriculture? J. Clean. Prod. 2017, 164, 258-264. [CrossRef]

103. Bowes, M.J.; Read, D.S.; Joshi, H.; Sinha, R.; Ansari, A.; Hazra, M.; Simon, M.; Vishwakarma, R.; Armstrong, L.K.; Nicholls, D.J. Nutrient and microbial water quality of the upper Ganga River, India: Identification of pollution sources. Environ. Monit. Assess. 2020, 192, 1-20. [CrossRef]

104. Sutton, M.; Raghuram, N.; Adhya, T.K.; Baron, J.; Cox, C.; de Vries, W.; Hicks, K.; Howard, C.; Ju, X.; Kanter, D. The Nitrogen Fix: From Nitrogen Cycle Pollution to Nitrogen Circular Economy. In Frontiers 2018/19: Emerging Issues of Environmental Concern; Pinya, S., Ed.; United Nations Environment Programme: Nairobi, Kenya, 2019; pp. 52-64.

105. De Mello, K.; Taniwaki, R.H.; de Paula, F.R.; Valente, R.A.; Randhir, T.O.; Macedo, D.R.; Leal, C.G.; Rodrigues, C.B.; Hughes, R.M. Multiscale land use impacts on water quality: Assessment, planning, and future perspectives in Brazil. J. Environ. Manag. 2020, 270, 110879. [CrossRef] [PubMed]

106. De Oliveira, L.M.; Maillard, P.; de Andrade Pinto, E.J. Application of a land cover pollution index to model non-point pollution sources in a Brazilian watershed. Catena 2017, 150, 124-132. [CrossRef]

107. Ferreira, P.; van Soesbergen, A.; Mulligan, M.; Freitas, M.; Vale, M.M. Can forests buffer negative impacts of land-use and climate changes on water ecosystem services? The case of a Brazilian megalopolis. Sci. Total Environ. 2019, 685, 248-258. [CrossRef]

108. Kelman, J. Water supply to the two largest Brazilian metropolitan regions. Aquat. Procedia 2015, 5, 13-21. [CrossRef]

109. Taniwaki, R.H.; Cassiano, C.C.; Filoso, S.; de Barros Ferraz, S.F.; de Camargo, P.B.; Martinelli, L.A. Impacts of converting low-intensity pastureland to high-intensity bioenergy cropland on the water quality of tropical streams in Brazil. Sci. Total Environ. 2017, 584, 339-347. [CrossRef] [PubMed]

110. De Mello, K.; Valente, R.A.; Randhir, T.O.; dos Santos, A.C.A.; Vettorazzi, C.A. Effects of land use and land cover on water quality of low-order streams in Southeastern Brazil: Watershed versus riparian zone. Catena 2018, 167, 130-138. [CrossRef]

111. Cruz, M.A.S.; de Azevedo Gonçalves, A.; de Aragão, R.; de Amorim, J.R.A.; da Mota, P.V.M.; Srinivasan, V.S.; Garcia, C.A.B.; de Figueiredo, E.E. Spatial and seasonal variability of the water quality characteristics of a river in Northeast Brazil. Environ. Earth Sci. 2019, 78, 68. [CrossRef]

112. Porfirio, Z.; Ribeiro, M.P.; Estevam, C.S.; Houly, R.L.; Sant'Ana, A.E.G. Hepatosplenomegaly caused by an extract of cyanobacterium Microcystis aeruginosa bloom collected in the Manguaba Lagoon, Alagoas-Brazil. Rev. De Microbiol. 1999, 30, $278-285$. [CrossRef]

113. De Magalhães, V.F.; Soares, R.M.; Azevedo, S.M. Microcystin contamination in fish from the Jacarepaguá Lagoon (Rio de Janeiro, Brazil): Ecological implication and human health risk. Toxicon 2001, 39, 1077-1085. [CrossRef]

114. Matthiensen, A.; Yunes, J.; Codd, G. Occurrence, distribution and toxicity of cyanobacteria from the Patos Lagoon estuary, southern Brazil. Rev. Bras. De Biol. 1999, 59, 361-376. [CrossRef] [PubMed]

115. Marc, B.; Diogo, F.Â.o.; Mauro, M.; Marc, P.; Ariadne, M. Occurrence of Cylindrospermopsis (Cyanobacteria) in 39 Brazilian tropical reservoirs during the 1998 drought. Aquat. Microb. Ecol. 2000, 23, 13-27. [CrossRef]

116. Chellappa, S.; Chellappa, N. Ecology and reproductive plasticity of the Amazonian cichlid fishes introduced to the freshwater ecosystems of the semiarid Northeastern Brazil. Adv. Fish Wildl. Ecol. Biol. 2004, 3, 317.

117. Chellappa, N.T.; Chellappa, S.L.; Chellappa, S. Harmful phytoplankton blooms and fish mortality in a eutrophicated reservoir of Northeast Brazil. Braz. Arch. Biol. Technol. 2008, 51, 633-641. [CrossRef]

118. Sommer, S.G.; Schjoerring, J.K.; Denmead, O. Ammonia emission from mineral fertilizers and fertilized crops. Adv. Agron. 2004, $82,82004-82008$.

119. Cunha-Zeri, G.; Ometto, J. Nitrogen emissions in Latin America: A conceptual framework of drivers, impacts, and policy responses. Environ. Dev. 2020, 100605. [CrossRef]

120. Abril, A.; Baleani, D.; Casado-Murillo, N.; Noe, L. Effect of wheat crop fertilization on nitrogen dynamics and balance in the Humid Pampas, Argentina. Agric. Ecosyst. Environ. 2007, 119, 171-176. [CrossRef]

121. Jobbágy, E.G. Servicios Hídricos de los Ecosistemas y su Relación con el uso de la Tierra en la Llanura Chaco-Pampeana; Instituto Nacional de Tecnología Agropecuaria: Buenos Aires, Argentina, 2011; pp. 163-185.

122. Carbó, L.; Flores, M.; Herrero, M. Well site conditions associated with nitrate contamination in a multilayer semiconfined aquifer of Buenos Aires, Argentina. Environ. Geol. 2009, 57, 1489-1500. [CrossRef]

123. MacDonald, A.M.; Taylor, R.G.; Bonsor, H.C. Groundwater in Africa: Is There Sufficient Water to Support the Intensification of Agriculture from 'Land Grabs'? In Handbook of Land and Water Grabs in Africa; Allan, J., Keulertz, M., Sojamo, S., Warner, J., Eds.; Routledge: London, UK, 2012; pp. 376-383, 488.

124. Usher, B. Issues of groundwater pollution in Africa. In Groundwater Pollution in Africa; Taylor \& Francis/Balkema: Leiden, The Netherlands, 2006; pp. 3-9.

125. Hegazy, D.; Abotalib, A.Z.; El-Bastaweesy, M.; El-Said, M.A.; Melegy, A.; Garamoon, H. Geo-environmental impacts of hydrogeological setting and anthropogenic activities on water quality in the Quaternary aquifer southeast of the Nile Delta, Egypt. J. Afr. Earth Sci. 2020, 172, 103947. [CrossRef]

126. Sarkar, D.; Baishya, L.K. Nutrient use efficiency. In Essential Plant Nutrients; Springer: Berlin/Heidelberg, Germany, 2017; pp. 119-146. 
127. Fixen, P.; Brentrup, F.; Bruulsema, T.; Garcia, F.; Norton, R.; Zingore, S. Nutrient/Fertilizer Use Efficiency: Measurement, Current Situation and Trends. In Managing Water and Fertilizer for Sustainable Agricultural Intensification; International Fertilizer Industry Association (IFA): Paris, France; International Water Management Institute (IWMI): Paris, France; International Plant Nutrition Institute (IPNI): Paris, France; International Potash Institute (IPI): Paris, France, 2015; pp. 8-38.

128. Ladha, J.K.; Pathak, H.; Krupnik, T.J.; Six, J.; van Kessel, C. Efficiency of fertilizer nitrogen in cereal production: Retrospects and prospects. Adv. Agron. 2005, 87, 85-156. [CrossRef]

129. Sheldrick, W.F.; Syers, J.K.; Lingard, J. A conceptual model for conducting nutrient audits at national, regional, and global scales. Nutr. Cycl. Agroecosystems 2002, 62, 61-72. [CrossRef]

130. Howarth, R.W.; Boyer, E.W.; Pabich, W.J.; Galloway, J.N. Nitrogen use in the United States from 1961-2000 and potential future trends. Ambio: A J. Hum. Environ. 2002, 31, 88-96. [CrossRef] [PubMed]

131. Kanter, D.R.; Bartolini, F.; Kugelberg, S.; Leip, A.; Oenema, O.; Uwizeye, A. Nitrogen pollution policy beyond the farm. Nat. Food 2020, 1, 27-32. [CrossRef]

132. Caviglia, O.; Rizzalli, R.H.; Monzon, J.P.; García, F.; Melchiori, R.; Martinez, J.J.; Cerrudo, A.; Irigoyen, A.; Barbieri, P.; Van Opstal, N.V. Improving resource productivity at a crop sequence level. Field Crop. Res. 2019, 235, 129-141. [CrossRef]

133. Reetz, H.F. Fertilizers and Their Efficient Use; International Fertilizer industry Association (IFA): Paris, France, 2016.

134. Baulch, H.M.; Elliott, J.A.; Cordeiro, M.R.; Flaten, D.N.; Lobb, D.A.; Wilson, H.F. Soil and water management: Opportunities to mitigate nutrient losses to surface waters in the northern Great Plains. Environ. Rev. 2019, 27, 447-477. [CrossRef]

135. Hefner, M.; Gebremikael, M.T.; Canali, S.; Serra, F.X.S.; Petersen, K.K.; Sorensen, J.N.; De Neve, S.; Labouriau, R.; Kristensen, H.L. Cover crop composition mediates the constraints and benefits of roller-crimping and incorporation in organic white cabbage production. Agric. Ecosyst. Environ. 2020, 296, 106908. [CrossRef]

136. Ferrante, A.; Nocito, F.F.; Morgutti, S.; Sacchi, G.A. Plant breeding for improving nutrient uptake and utilization efficiency. In Advances in Research on Fertilization Management of Vegetable Crops; Springer: Berlin/Heidelberg, Germany, 2017; pp. 221-246.

137. Shi, P.; Zhang, Y.; Song, J.; Li, P.; Wang, Y.; Zhang, X.; Li, Z.; Bi, Z.; Zhang, X.; Qin, Y. Response of nitrogen pollution in surface water to land use and social-economic factors in the Weihe River watershed, northwest China. Sustain. Cities Soc. 2019, 50, 101658. [CrossRef]

138. Tei, F.; De Neve, S.; de Haan, J.; Kristensen, H.L. Nitrogen management of vegetable crops. Agric. Water Manag. 2020, $240,106316$. [CrossRef]

139. Thompson, R.B.; Incrocci, L.; van Ruijven, J.; Massa, D. Reducing Contamination of Water Bodies from European Vegetable Production Systems; Elsevier: Amsterdam, The Netherlands, 2020.

140. Padilla, F.M.; Farneselli, M.; Gianquinto, G.; Tei, F.; Thompson, R.B. Monitoring nitrogen status of vegetable crops and soils for optimal nitrogen management. Agric. Water Manag. 2020, 241, 106356. [CrossRef]

141. Gallardo, M.; Elia, A.; Thompson, R.B. Decision support systems and models for aiding irrigation and nutrient management of vegetable crops. Agric. Water Manag. 2020, 106209. [CrossRef]

142. Tang, Y.; Yang, C. Which Factors Influence Chinese Farmers to Adopt Formulated Fertilization Technology? In Proceedings of the IOP Conference Series: Earth and Environmental Science, Bangkok, Thailand, 14 December 2019; p. 012039. [CrossRef]

143. Daxini, A.; O’Donoghue, C.; Ryan, M.; Buckley, C.; Barnes, A.P.; Daly, K. Which factors influence farmers' intentions to adopt nutrient management planning? J. Environ. Manag. 2018, 224, 350-360. [CrossRef]

144. Okumah, M.; Yeboah, A.S.; Nkiaka, E.; Azerigyik, R.A. What determines behaviours towards water resources management in a rural context? Results of a quantitative study. Resources 2019, 8, 109. [CrossRef]

145. Wang, Y.; Zhu, Y.; Zhang, S.; Wang, Y. What could promote farmers to replace chemical fertilizers with organic fertilizers? J. Clean. Prod. 2018, 199, 882-890. [CrossRef]

146. Fezzi, C.; Hutchins, M.; Rigby, D.; Bateman, I.J.; Posen, P.; Hadley, D. Integrated assessment of water framework directive nitrate reduction measures. Agric. Econ. 2010, 41, 123-134. [CrossRef]

147. Kanter, D.R.; Chodos, O.; Nordland, O.; Rutigliano, M.; Winiwarter, W. Gaps and opportunities in nitrogen pollution policies around the world. Nat. Sustain. 2020, 3, 956-963. [CrossRef]

148. Klages, S.; Heidecke, C.; Osterburg, B.; Bailey, J.; Calciu, I.; Casey, C.; Dalgaard, T.; Frick, H.; Glavan, M.; D’Haene, K.; et al. Nitrogen Surplus-A Unified Indicator for Water Pollution in Europe? Water 2020, 12, 1197. [CrossRef]

149. Smith, L.E.; Siciliano, G. A comprehensive review of constraints to improved management of fertilizers in China and mitigation of diffuse water pollution from agriculture. Agric. Ecosyst. Environ. 2015, 209, 15-25. [CrossRef]

150. Newbould, P. The use of nitrogen fertiliser in agriculture. Where do we go practically and ecolotically? Plant Soil 1989, 115, 297-311. [CrossRef]

151. Böcker, T.; Finger, R. European Pesticide Tax Schemes in Comparison: An Analysis of Experiences and Developments. Sustainability 2016, 8, 378. [CrossRef]

152. Hautakangas, S.; Ollikainen, M. Nutrient Trading Between Wastewater Treatment Plants in the Baltic Sea Region. Environ. Resour. Econ. 2019, 73, 533-556. [CrossRef]

153. Adenuga, A.H.; Davis, J.; Hutchinson, G.; Patton, M.; Donnellan, T. Analysis of the effect of alternative agri-environmental policy instruments on production performance and nitrogen surplus of representative dairy farms. Agric. Syst. 2020, 184, 102889. [CrossRef] 
154. Beeckman, F.; Motte, H.; Beeckman, T. Nitrification in agricultural soils: Impact, actors and mitigation. Curr. Opin. Biotechnol. 2018, 50, 166-173. [CrossRef]

155. Berbel, J.; Esteban, E. Droughts as a catalyst for water policy change. Analysis of Spain, Australia (MDB), and California. Glob. Environ. Chang. 2019, 58, 101969. [CrossRef] 